\title{
Round One? Judge Issues Rulings in Long-awaited Copyright Infringement Lawsuit Against Georgia State University*
}

\author{
Linda K. Enghagen \\ University of Massachusetts at Amherst
}

\begin{abstract}
Long-awaited rulings from the copyright infringement lawsuit provide the most specific guidance available to date regarding fair use of certain types of materials in e-reserves systems and online course management systems. Unless successfully appealed or otherwise overturned, this case represents a significant victory for Georgia State University specifically and higher education in general. In addition to rejecting the 1976 Classroom Copying Guidelines for Books and Periodicals as an appropriate legal standard for fair use, the case holds that semester-to-semester use of the same material is permitted under fair use. Further, at least for non-fiction books, this case provides somewhat formulaic standards for evaluating fair use. Finally, the potential financial implications of this case are analyzed and suggestions for institutional due diligence are recommended.
\end{abstract}

\section{INTRODUCTION}

While the trial ended in July of 2011, it took Judge Orinda Evans eleven months to issue a ruling in the closely watched copyright infringement case brought by Cambridge University Press, Oxford University Press, Inc. and Sage Publications, Inc. against Georgia State University [1]. Originally filed on April 15, 2008 [2], this case represents the first time a university was confronted with allegations of massive copyright infringement resulting from posting copyright protected works to its e-reserves and online course management systems.

As characterized in the original complaint, the publishers accused Georgia State University of engaging in the "systematic, widespread, and unauthorized copying and distribution of a vast amount of copyrighted works...through a variety of online systems and outlets utilized...for the digital distribution of course reading material...without the requisite authorization and appropriate compensation to the copyright owners of such materials" [2, p. 2]. More specifically, the three publishers claimed that "with the University's encouragement, hundreds of professors employed by Georgia State ... compiled thousands of copyrighted works, made them available for electronic distribution, and invited students to download, view, and print such materials without permission from the copyright owners. As of February 19, 2008, the Georgia State Library's electronic course reserves system listed over 6700 total works available for some 600-plus courses” [2, p. 3-4].

In many respects, the case against Georgia State University is the extension to earlier lawsuits against Kinko’s Graphics Corp. [3] and Michigan Documents Services [4]—cases that resulted in publisher 
victories. In the Kinko's and Michigan Documents Services cases, the facts were straightforward and essentially identical. Each involved a private business generating profits from the sale of course packs for which no permissions were sought and no royalties paid. Each party attempted to defend itself claiming permissions in the name of fair use allowed copying and distribution of course pack materials selected for use in specific courses by specific professors in non-profit educational settings. In each case, the courts disagreed. While acknowledging the end use of the course packs was for non-profit educational purposes, both the copying and distribution channels were viewed to be for-profit in nature. Consequently, both Kinko's and Michigan Documents Services lost their fair use arguments and were found to be engaging in copyright infringement [3, 4]. Though less well known, a third course pack case against another Michigan-based copy venture ended in a similar outcome [5]. In Blackwell Publishing, Inc., Elsevier, Inc., Oxford University Press, Inc., Sage Publications, Inc., and John Wily \& Sons, Inc. v. Excel Research Group, LLC d/b/a Excel Test Preparation, Coursepacks \& Copies, and Norman Miller, venture owner Normal Miller attempted to avoid the problems of Kinko's and Michigan Documents Services by implementing a self-service based model for course packs [5]. That is, at Miller's copy shop, professors provided a compilation of readings for a particular course from which the copy shop then made a "master" version. Students then purchased a copy of the course pack by requesting the "master" which they copied themselves at one of the shop's copy machines. Miller argued because students made the copies themselves, there was no infringement on his part. Disagreeing with Miller's characterization, the judge stated:

At bottom, this case is not seriously distinguishable from [Michigan Documents Services]. The fact that the students push a button on a copier in the manner described is of no significance. Excel's assertion that it has no inventory and simply offers copying services is not correct - it has an inventory of copyrighted materials given it by professors, some of whom even state in their course syllabi that the material is available for 'purchase' at Excel. ... Simply put, copyright law should not turn on who presses the start button on a copier. Excel's actions violate the publishers' copyrights [5, p. 13-14].

Apart from references related to digital distribution in the lawsuit against Georgia State University, the underlying allegations are remarkably similar to those in the three (3) copy shop cases above. Georgia State University professors compile course packs which are made available to students without permission from, or royalties paid to, copyright holders. As has been made clear in all three (3) copy shop cases above, when this is undertaken by a private business profiting from the sale of course packs, it constitutes copyright infringement [3, 4, 5] regardless of "who presses the start button on the copier" [5]. Nevertheless, even at the time of the Kinko's case, the judge left room for a different outcome if the copying and distribution occurred on-campus: "Expressly, the decision of the court does not consider copying performed by students, libraries, nor on-campus copy shops, whether conducted for-profit or not" [3, footnote 13]. This case begins to offer answers to the parameters of fair use when undertaken on the campus of a public, non-profit university.

\section{SOVEREIGN IMMUNITY AND PUBLIC UNIVERSITIES}

One somewhat unexpected aspect of the Georgia State University case is it was brought against a public university. This is somewhat unexpected because of limitations found in the $11^{\text {th }}$ Amendment to the U.S. Constitution regarding the use of federal courts against state governments. The $11^{\text {th }}$ Amendment sovereign immunity doctrine was designed to act as a check and balance between the powers of the state and federal governments; it protects states from being sued in federal courts. The precise language of the amendment is as follows: "The Judicial power of the United States shall not be construed to extend to any suit in law or equity, commenced or prosecuted against one of the United States by Citizens of another State, or by Citizens or Subjects of any Foreign State” [6]. Consequently, in most instances, state governments, and thereby state institutions and state officials, cannot be sued in federal courts. Nevertheless, like other provisions of the U.S. Constitution and its amendments, this rule is not absolute. 
There are limited circumstances under which such lawsuits are permitted to proceed. This George State University case fell within those limited circumstances.

In a September 30, 2010 ruling, Judge Evans noted that it is an undisputed fact of this case that the state officials being sued here "are arms of the State of Georgia and they are being sued in their official capacities" [7, p. 13]. In her ruling which permitted the case to proceed, she acknowledged that the $11^{\text {th }}$ Amendment prohibition on federal court lawsuits against states, state institutions, and state officials applies when the suit is looking for monetary damages or otherwise seeks a remedy for past wrongs. However, this case did neither. In the lawsuit, publishers asked the court to issue an injunction permanently preventing GSU from continuing to commit what it viewed as being copyright infringement. In concluding that the lawsuit falls under an exception to the general rule of state sovereign immunity, Judge Evans noted: “... under the long-recognized exception to this rule ... suit against Defendants is allowed to the extent that it seeks 'prospective equitable relief to end continuing violations of federal law.' The 'ongoing and continuous' requirement is satisfied where there is a threat of future violations of federal law that may be remedied by prospective relief" [7, p. 13].

While Judge Evans permitted the GSU lawsuit to proceed against university officials, none were alleged to have personally violated the law. Each was sued by virtue of his or her position and related area of responsibilities. From a legal standpoint, this is an important distinction because sovereign immunity does not necessarily apply to state employees who are accused of personally participating in perpetrating the violation. For example, in 2006, a copyright infringement lawsuit brought against the trustees of the California State University System and Robert Rauch, an employee of San Diego State University (SDSU) accused Rauch of personally infringing a copyright held by a private marketing firm when he prepared an economic impact study as part of his responsibilities as the Director of SDSU's Center for Hospitality and Tourism Research [8]. Consequently, when ruling on the application of sovereign immunity in this case, the judge agreed that sovereign immunity protected SDSU, but found it did not protect Rauch.

State sovereign immunity extends to government officials that are sued for damages in their official capacity. An individual capacity suit against a government official is one that directly attaches that individual's assets and is one that will not lead to monetary liability of the state. The deciding factor for ascertaining whether a suit is an official capacity suit or an individual capacity suit is not how the suit is labeled by the plaintiff, but rather the nature of the suit. Where the suit is against the individual, the individual is not automatically immune from suit by virtue of the fact that the act was undertaken in the course of his or her employment. ... Based upon the [facts alleged in the complaint] which includes allegations that Rauch personally engaged in the infringing behavior, the Court finds Plaintiff seeks relief from Rauch in his individual capacity as well as official capacity. Accordingly, Rauch is not entitled to sovereign immunity from the suit seeking relief against him in his individual capacity (citations omitted) [8, p. 7-9].

In other words, while the case against SDSU was dismissed, the case against Rauch continued — not in his capacity as an employee of SDSU_-but against him personally. According to news accounts, the case was ultimately settled with SDSU paying the marketing firm \$15,000 on Rauch's behalf [9]. The critical distinction made by the court in the case illustrates an important but easily misunderstood dimension of the sovereign immunity doctrine. It protects state institutions and employees sued in their official capacities, but does not necessarily protect state employees accused of personally engaging in illegal behavior even as part of or related to the responsibilities of their positions.

\section{POTENTIAL HIGH STAKES GOING FORWARD}

Given the sovereign immunity protection for state institutions and officials, the publishers could not successfully bring this lawsuit asking for monetary damages for the alleged past infringements. Consequently, it might appear from a financial perspective, this case is of little consequence to both the 
publishers and GSU. However, that is not the case. The financial ramifications of this litigation are potentially high. In addition to the costs of the lawsuit itself, there is the possibility of increased costs associated with compliance such as those for permissions fees. The following examines various financial dimensions to this case.

\section{A. Costs Borne for the Litigation Itself}

While judges sometimes have the discretion to order a losing party to pay attorney costs and fees of the winning side, at least at the outset, both the publishers and GSU must bear the cost of bringing and defending this litigation. As it turns out, the publishers received significant assistance in this regard. According to court filings, the publishers identify both the Copyright Clearance Center and the Association of American Publishers as "having either a financial interest in or other interest which could be substantially affected by the outcome of this particular case" [10]. While this filing does not specify the nature of the interest either group has in the lawsuit, a September 2010 Order revealed that the Copyright Clearance Center (CCC) financed 50\% of the litigation's costs [7, p. 10 at footnote 2]. When the judge's order made public the specific nature and extent of the Copyright Clearance Center's involvement, it was not well received in academic circles. For example, Charles B. Lowry, the Executive Director of the Association of Research Libraries was wrote a letter to Tracey L. Armstrong, the President and CEO of the CCC, objecting to its involvement. Dated November 11, 2010, Lowry wrote:

On behalf of the Association of Research Libraries, I am writing to express our deep disappointment with the decision by the Copyright Clearance Center (CCC) to underwrite $50 \%$ of the plaintiffs' costs in the litigation by three publishers against Georgia State University. We learned of the CCC’s action in the recent ruling by Judge Orinda Evans of the Federal District Court in Atlanta.

As the CCC notes on its website, the not-for-profit organization was founded "by a collaboration of content creators, content publishers, and content users." The CCC also notes that it "serves the interests of those who supply content as well as those who use it." Balancing the interests of these communities can be a challenging task, and many efforts have been made over the years to that end with the understanding that collaboration is a far more successful strategy. Unfortunately, this action by the CCC signals to the content user community that the CCC no longer seeks to serve the interests of all of the partners in the scholarly communications enterprise.

We write in hopes that the CCC will seriously reconsider, going forward, its role and participation in litigation against members of the academic community [11].

According to Publishers Weekly, when it contacted the CCC for a response to Lowry's letter, a CCC spokesperson defended their involvement by pointing out that the case is meant to clarify fair use and is asking only for an injunction, not monetary damages. Further, according to the spokesperson, "There is nothing inconsistent, in our view, between acting as a good faith intermediary to facilitate licensing while at the same time supporting efforts to address outlying instances of egregious copyright infringement" [12]. In her May 11, 2012 ruling, Judge Evans further clarified the origins of this litigation when she noted that "the Court infers that CCC and AAP organized the litigation and recruited the three plaintiffs to participate. AAP and CCC are each paying one-half of Plaintiffs' litigation expenses including attorneys' 
fees in this case” [19]. Whether either organization experiences any negative repercussions as the result of these further disclosures remains to be seen.

As noted earlier, it is true that the case does not ask for monetary damages for the alleged copyright infringements. However, in addition to seeking a permanent injunction, the lawsuit does ask for attorneys' fees and expenses [2, p. 29]. Consequently, to the extent GSU loses, it can be ordered to reimburse the publishers for their costs; given the identification of the CCC and AAP as parties who underwrote the financial cost to the publishers, they stand to receive some share of any reimbursement. Further, the prospect remains the CCC and AAP may seek recruitment of other potential publishers for further litigation (i.e. test cases) against other institutions.

\section{B. GSU's Expenditures for Electronic Databases and CCC Licensing Fees}

The fees and expenses specifically associated with bringing and defending this lawsuit represent a onetime cost borne by those involved. Understanding the high stakes nature of this litigation from a financial standpoint requires a more detailed examination of GSU's practices and related expenditures in contrast to the claims asserted by the publishers.

In her September 30, 2010 order, the judge noted that the GSU library spends between \$4 and \$5 million on materials, with roughly half of the expenditure going to the licensing of electronic journal databases [7, p. 10 at footnote 2]. In addition, over the ten year period from 1998 to 2008, GSU "paid \$18,905.42 directly to the CCC for licensing fees" [Id.] In other words, in addition to already spending between \$2 and \$2.5 million on licensing fees for electronic journals, GSU also spent, on average, an additional $\$ 1,900$ per year in permissions fees to the CCC. Compare that additional $\$ 1,900$ per year in permissions fees to the cost GSU would incur for an Annual Academic Copyright License from the CCC. According to Tom Allen, president and CEO of the Association of American Publishers, such a license would cost GSU \$114,000 annually (not including the one-time administrative fee): "What would be the annual cost to Georgia State University if it subscribed to a blanket Annual Academic Copyright License? The answer is $\$ 114,000$ in rights-holder royalties per year plus a one-time, first-year-only administrative charge of $20 \%$ of that amount. With an estimated 30,400 students at GSU, $\$ 114,000$ works out to about $\$ 3.75$ per student. About the cost of one medium-sized Starbucks drink” [13]. Even without the one-time administrative fee, the annual license would cost GSU \$1,140,000.00 over ten years instead of the $\$ 18,905.42$ they paid.

\section{Permissions Fees for the Alleged Infringements Per the Publishers' Calculations}

In the actual lawsuit, the judge approached the permissions fees question by first narrowing the alleged infringements, and then asking for an evaluation of royalties owed under the CCC's permission system on an item-by-item basis. In early August 2010, Judge Orinda Evans ordered each side to start to get specific. That is, the publishers were ordered to identify the allegedly infringing works for three terms: the 2009 Maymester, the 2009 summer semester, and the 2009 fall semester. The judge's order directed the publishers to compile the following information.

This list of courses must be grouped by semester and must include:

1. The title of the course;

2. The instructor teaching that course during that semester;

3. The title of the work that was allegedly infringed when it was electronically distributed for use in that course; 
4. The owner of the copyright of that work;

5. A brief description of that work including its total number of pages and chapters; and

6. The number of pages and chapters of that work that were electronically distributed for use in that course during that semester [14].

The publishers were further ordered to compile information concerning the costs of the alleged infringements [15].

Georgia State University was given orders too. The university was ordered to respond to the information submitted by publishers and, in addition, to identify all books and course packs students were required to purchase for each course on the list [14, 15]. Finally, the court ordered GSU to report the number of courses taught during each of the three terms in question [14]. One can only imagine the bills each side received from the hours of lawyers laboring at their hourly rates to compile it all. What is more interesting, however, is what the court documents reveal about the dollars at stake for publishers and copyright clearance companies such as the Copyright Clearance Center (whose fee structure was used to calculate permissions fees) [16].

The data for the 2009 fall semester provides a snapshot of the revenue publishers believe they lost by their book chapters being distributed via e-reserves without any permissions royalties paid by GSU [17]. Based on GSU's response, the school acknowledged thirty-one (31) courses taught at GSU distributed a total of fifty-seven (57) chapters from books identified by the publishers. Interestingly, in the vast majority of the cases (45 out of 57) only one (1) chapter from a given book was distributed via ereserves. That represents over 95\% of the cases. In two (2) instances, one (1) chapter plus part of a second chapter were distributed. In the remaining cases, there were six (6) instances in which two (2) chapters were distributed, two (2) instances in which three (3) chapters were distributed, one (1) instance in which four (4) chapters were distributed, and one (1) instance in which eight (8) chapters were distributed. Even in the eight (8) chapter case, only 186 pages of the 1,126 page volume were ultimately distributed. On the whole, the vast majority of the instances did not involve copying massive portions of individual books. Indeed, it is highly likely that many faculty members believe taking a single chapter from a book is comfortably within the parameters of fair use in most situations. Clearly, the publishers did not share the same view. It is easy to see why the publishers viewed it differently when examined from the perspective of the potential lost revenues.

Looking at fall 2009 data provided by GSU in its court filings, the class sizes reported for the period ranged from one to one hundred fourteen (1-114) students with most courses having fewer than fifty (50) students enrolled [17]. Based on the actual enrollment figures for each course and the permissions fees the Copyright Clearance Center charges for the chapters in question (which includes a \$3 service charge for each permission request), GSU's permissions bill for that semester would have been \$7,153.75. Assuming fall 2009 represents a typical semester, this translates into $\$ 14,307.50$ for the academic year. This excludes GSU's summer and Maymester sessions, and further, does not include permissions for works posted to online classes or course web sites. Clearly, with complete data, the permissions bill would increase significantly. And that is just at GSU.

While that may not sound like an enormous expenditure for a given institution, the revenues at stake quickly become significant when put in context. According to data from the U.S. Department of Education's Institute of Education Sciences, in 2009-2010, there were 4,495 colleges, universities and community colleges in the United States [18]. Of these, 2,774 were four-year colleges and universities, and 1,721 were 2-year institutions. It is reasonable to assume that many of these institutions utilize some combination of e-reserves, online classes, and course web sites in a manner similar to GSU. If only one thousand $(1,000)$ of those institutions act similarly to GSU in terms of volume and usage of course materials, it means lost permissions revenue of $\$ 14,307,500$. And, this figure represents the lost revenues to only three (3) publishers. By the numbers, the stakes are clear-the outcome of the case will 
significantly impact the business model of the academic publishing industry for decades to come.

\section{LONG AWAITED FAIR USE RULING}

Judge Evans issued an approximately 350 page opinion on May 11, 2012 [19]. In addition to laying out the general factual framework of the case and providing a close examination of the nature of the fair use defense as a matter of law, the order provides the most detailed analysis provided by a court to date of the application of those rules to seventy-five (75) alleged copyright infringements in an educational setting. (At trial, seventy-five (75) alleged infringements were litigated. The opinion analyzes seventy-four (74) different alleged infringements. One excerpt was used twice; that is, it was used in the same course offered in two different semesters.) The judge found only five instances in which she concluded that faculty members posted electronic materials in a manner violating fair use. As a result, it may be easy to conclude that this is a major victory for GSU, in particular, and higher education in general. Nevertheless, a closer examination of her ruling reveals a far more mixed outcome than might appear.

\section{A. Finds of Fact}

By the time the case went to trial, the basic question in front of the judge was whether the application of GSU's 2009 Copyright Policy resulted in violations of fair use. Under that policy, faculty members were provided a fair use checklist to evaluate whether permissions were required for use of copyright protected. As described by Judge Evans, faculty members were instructed to consider each of the four fair use factors [19, p. 39]. If at least three of the four factors favored fair use, fair use was presumed to apply. If only one factor favored fair use, permission was supposed to be obtained. And if two of the factors favored fair use, they were instructed to weigh the facts on both sides before drawing a conclusion. GSU offered training to faculty in the application of the policy and use of the fair use checklist. According to trial testimony: "Professors who attended these sessions were told that there was no across-the-board answer to [how much copying was allowed under fair use], but that under fifteen percent would likely be safe and that under ten percent would be 'really safe' ...” [19, p.39]. At trial, the publishers raised seventy-five (75) instances of alleged copyright infringement arguing GSU's policy and its application by faculty members illegally exceeded the limits of fair use.

\section{B. Framework for Fair Use Analysis}

In laying out the framework for applying fair use, Judge Evans established the threshold question to be answered for each alleged infringement. That is, in each instance, the relevant publisher had to prove ownership of a valid copyright to the work allegedly misused [19, p. 44]. If a publisher could not satisfy that threshold, the claim of alleged infringement failed for that reason and no fair use analysis was undertaken. When ownership of a valid copyright was proven, the court then undertook a detailed analysis of the fair use factors. Before examining alleged infringements individually, the court spelled out its interpretation of the manner in which each of the four factors should be applied.

\section{First Fair Use Factor: Purpose and Character of the Use Including Whether Such Use is of a Commercial Character or is for Nonprofit Educational Purposes}

While Judge Evans pointed out that use for nonprofit educational purposes did not automatically qualify as a fair use, she did conclude that the first factor favored GSU. In arriving at this conclusion, she noted all copying was done as part of teaching and scholarship. Further, she rejected the publishers' argument that the first factor must favor them because the copied materials were "mirror images" and not transformative [19, p. 49-50]. In doing so, she quoted the U.S. Supreme Court's decision in an unrelated copyright infringement, which stated: "The obvious statutory exception to this focus on transformative uses is the straight reproduction of multiple copies for classroom distribution” [19, p.50].

\section{Second Fair Use Factor: Nature of the Copyrighted Work}


Like the first factor, the judge concluded the second factor favored GSU [19, p. 54]. In arriving at this conclusion, she pointed out that each case of alleged copyright infringement involved the use of excerpts of books chapters that are works of nonfiction "intended to inform and educate" [19, p. 52]. Generally, courts find this factor to favor copyright owners when the copied works are more creative in nature. In contrast, works of nonfiction that are more factual in nature receive less protection and their use is more likely to be permitted under fair use.

\section{Third Fair Use Factor: Amount and Substantiality of the Portion Used in Relation to the Copyrighted Work as a Whole}

Undoubtedly, Judge Evans' framework for the application of the third fair use factor is simultaneously one of the most useful and controversial aspects of this opinion. It is useful in that it provides specific and somewhat formulaic answers to some fair use questions. For that same reason, it is controversial. This portion of the opinion begins by acknowledging that this factor requires both quantitative and qualitative considerations [19, p. 55]. The judge then goes on to make the following rulings of law:

- The "Agreement on Guidelines for Classroom Copying in Not-For-Profit Educational Institutions with Respect to Books and Periodicals" is not legally binding as the standard for determining fair use [19, p. 55-59].

- Copying that is de minimis does not constitute copyright infringement [19, p. 59].

- Determination of the portion used requires evaluating the portion copied in relation to the entire work. The entire work includes not only the text within each chapter but also includes the material "before and after the chapter text of the book" such as the table of contents, acknowledgements, preface, foreword, afterword, and indices [19, p. 60].

- While fair use does not permit professors to copy the "heart of the work" without obtaining permission, an excerpt it not automatically the "heart of the work" by virtue of a professor selecting it for classroom use [19, p. 67-68].

- Fair use law permits professors to use the same excerpt from one semester to the next [19, p. 71].

- It is not necessary to obtain permission to use an excerpt of a nonfiction book when the excerpt used is not the "heart of the work" and no more than $10 \%$ of the work and the work either has no chapters or has fewer than 10 chapters [19, p. 88].

- It is not necessary to obtain permission to use an excerpt of a nonfiction book when the excerpt is not the "heart of the work," is limited to 1 chapter (or its equivalent), and the book has 10 or more chapters [19, p. 88].

\section{Fourth Fair Use Factor: The Effect of the Use on the Potential Market for or Value of the Copyrighted Work}

Judge Evans defines the primary concern of the fourth factor to be "market substitution. Where the copyrighted original and defendant's infringing work are identical, defendant's infringing copy substitutes directly for the copyrighted original” [19, p.73-74]. She notes there are two situations that must be considered relative to the market for or value of the copied work: the market for the entire book and the market for licensed permissions [19, p. 74-75]. When evaluating the market for the entire book, the copied excerpt must be looked at in contrast to the whole. When evaluating the market for and value of licensed permissions, this must be analyzed relative to whether "licenses for excerpts of the works at issue are easily accessible, reasonably priced, and ... in a format which is reasonably convenient for users" [19, p. 75]. In the case of the market for permissions, she concluded: "factor four weighs heavily in [the publishers'] favor when permissions for digital excerpts are readily available. If excerpts are not readily available ... factor four weighs in [GSU's] favor” [19, p. 80].

\section{Application of Fair Use Framework to Individual Claims of Copyright Infringement}


In applying the fair use framework to individual claims of copyright infringement, the judge first determined whether the relevant publisher proved ownership of a valid copyright to the allegedly infringed work. If not, no fair use analysis was undertaken and the publisher lost on that claim. Of the seventy-five (75) cases of alleged infringement evaluated, the judge found sixteen (16) instances in which the publisher could not prove ownership of a valid copyright [19, p. 89-337]. In many of these instances, the problem related to the publishers' inability to produce contracts between the publisher and author(s) documenting who owned the copyright.

The second issue analyzed in each case related to whether the copying was "de minimis" and therefore not a copyright infringement. The judge found this to be true in ten (10) instances [19, p. 89-337]. In seven (7) of these cases, an excerpt of a copyright protected work was posted to an e-reserves system, but was not actually used by students as evidenced by the low number (usually three (3) or fewer) of "hits" (number of times accessed). In addition, there were three (3) other situations the court classified as "di minimis." One occurred when an excerpt of a book was posted, but was also from a book the students were required to purchase for the course. The second involved a situation in which an excerpt was posted, but the course was later cancelled due to low enrollment. In the third situation, an excerpt was posted but was later removed when the instructor realized the library did not own the book from which the excerpt originated.

For the remaining forty-nine (49) alleged copyright infringements, the court evaluated each one by applying the rules for each of the four fair use factors. After doing so, the court found:

- Twenty-four (24) instances in which GSU prevailed because the excerpt posted was within the limits established. That is, for books with fewer than ten (10) chapters or no chapters at all, the posted excerpt was less than $10 \%$ of the total pagination.

- Nineteen (19) instances in which GSU prevailed because the publisher did not offer a permissions program for digital copies or the evidence showed the market for permissions was small.

- Five (5) instances in which GSU violated fair use. Each violation involved the same type of situation. In each instance, the challenged excerpt was taken from a book that had more than ten (10) chapters and in each instance the excerpt exceeded the limit established by the court (i.e. no more than one (1) chapter or its equivalent). In addition, it is important to note that one of these instances involved an out of print book. Despite the fact it was out of print, the publisher was able to prove the market for permissions for this work was large. Consequently, the judge found copyright infringement.

While it is tempting to look at the fact that the court found only five (5) instances of copyright infringement as a major victory for GSU, in particular, and higher education in general, a closer look reveals a more mixed result. For example, of the ten (10) cases in which the court found no violation under its de minimis standard, two (2) involved the use of excerpts in excess of the court's $10 \%$ limit and would have resulted in violations had they been actually accessed by students in the respective courses. Similarly, of the sixteen (16) instances in which the publishers could not prove ownership of a valid copyright, six (6) involved instances in which the court's established limits were exceeded. To be sure, particularly in light of this decision, publishers will be more careful to properly document their publishing contracts with authors to easily avoid this problem from arising in the future. Finally, of the nineteen (19) instances in which the court found GSU's use to qualify as fair use, eight (8) would have constituted copyright infringement if the publisher offered a digital permissions program and proved a sufficiently large permissions market.

There are two important points to be made in this regard. First, in response to this ruling, publishers will be far more likely to routinely offer a digital permissions program for more of their collections. Second, once digital permissions are made available, there is no way to know whether the permissions market for a particular excerpt is large or small. That information is proprietary and in the absence of litigation, the 
publishers are not required to disclose it. Consequently, as Judge Evans noted, “ The only practical way to deal with factor four in advance [of litigation] is to assume that it strongly favors the plaintiff-publisher (if licensed digital excerpts are available)" [19, p. 338]. In the end, while it is true the court found only five (5) copyright infringements, with relatively minor changes in the facts of a number of the remaining claims, it could easily have been twenty-one (21) cases instead of five (5).

\section{DID THE PUBLISHERS GET WHAT THEY WANTED?}

The publishers got two important things out of this litigation. The court did find five (5) instances of copyright infringement that were caused by GSU's 2009 Copyright Policy. Referring to those violations the court noted: “...the policy did not limit copying in those instances to decidedly small excerpts as required ... Nor did it proscribe the use of multiple chapters from the same book. Also, the fair use policy did not provide sufficient guidance in determining the 'actual or potential effect on the market or the value of the copyrighted work,' a task which would be likely to be futile for prospective determinations (in advance of litigation)" [19, p. 337-338]. Further, the judge provided the publishers with a blue print for digital permissions by pointing out that: "The only practical way [for faculty members] to deal with factor four in advance likely is to assume that it strongly favors the plaintiff-publisher (if licensed digital excerpts are available)" [19, p. 338]. In other words, if a publisher provides a digital permissions program, faculty members are prudent to assume this factor favors the publisher and not the educational institution.

While the May 11, 2012 ruling discusses the judge's findings relative to copyright infringement and fair use, it does not address other aspects of the publishers' proposed injunction [20]. For example, in their proposed injunction, the publishers also asked the judge to include the following in her rulings:

- $10 \%$ Limit Per Course: only 10\% of materials in course could be used under fair use.

- Training: GSU should be required to develop and implement copyright compliance training program.

- Copyright Compliance Certification Requirements: designated copyright compliance employee, certification of compliance for three (3) years, and faculty certification documenting the posting of electronic course materials.

The judge issued her second post-trial order in the case on August 10, 2012 in which she declined to rule in favor of the publishers on these and other matters [21].

This second ruling specifically orders GSU to "maintain copyright policies” consistent with the May 11, 2011 ruling and to "disseminate to faculty and relevant staff at Georgia State the essential points of this Court's ruling” [21, p. 11]. Beyond that, it provides additional general guidance on the application of fair use in educational environments. Judge Evans unequivocally states that the application of fair use "is conditioned on [the] strict observance” of the following requirements:

- Access to the materials must be restricted to enrolled students, in a secure environment, and "only for the term of the course;"

- Institutional policies must be in place prohibiting students from further distributing the materials to others;

- Each time students access such materials, they must be "reminded of the limitations of the copyright laws;” and

- All materials used "must fill a demonstrated, legitimate purpose in the course curriculum and must be narrowly tailored to accomplish that purpose" [21, p. 9].

There are three other aspects of the August 2012 order that are noteworthy as well. First, while it was not directly litigated in the case, Judge Evans does comment on the application of her ruling to textbooks. Essentially, she concludes the publishers' nonfiction books at the center of the GSU lawsuit are not textbooks due to the fact that their intended readership is broader than students enrolled in particular 
courses [21, p. 5-6]. Consequently, she rules that the holdings from this case do not apply to textbooks [21, p. 5]. Second, she offers some guidance on the upper limit of fair use. To do so, she points to one of the instances of alleged infringement litigated in this case in which a professor used $18.52 \%$ of the pages of a book for which there was no mechanism to obtain electronic permissions. She found this to qualify as a fair use because there was no reasonably available method to obtain permission. Nevertheless, she points out that "the 18.52 percent amount likely is close to loss of fair use protection" [21, p. 10].

The third and perhaps most surprising ruling in this order relates to attorneys' fees and costs. In copyright infringement cases such as this, a judge has the discretion to award attorneys' fees and costs to the side that wins the case. Despite the fact that the judge found GSU to have committed copyright infringement in five (5) instances, she concluded that GSU was the "prevailing party" entitled to attorneys' fees and costs [21, p. 14]. In doing so, she pointed out that GSU lost in five (5) instances but prevailed on the remaining ninety-four (94) instances of alleged infringement. Further, in this ruling as in the May 11, 2012 ruling on the merits of the copyright infringement allegations, she noted that GSU made a good faith effort to comply with copyright and fair use law [20, p. 338; 21, p. 11]. In contrast, she criticized the publishers for pursuing too many weak claims which she dismissed but which nevertheless "significantly increased [GSU's] cost of defending the suit” [21, p. 14]. On September 30, 2012, Judge Evans issued her ruling on attorneys' fees and costs by awarding GSU a "reasonable attorneys' fee in the amount of “\$2,861,348.71 and costs in the amount of $\$ 85,746.39$ ” [22, p. 2].

\section{CONCLUSION}

The publishers wasted no time in indicating their intention to appeal the outcome of this case. At this point, court filings indicate their intention to appeal every order issued in this case [23, p. 1; 24, p. 1]. Clearly, the rulings in this case represent but round one in legal battle between educational institutions and publishers over what is and is not permitted under the ambit of fair use. While the appeals wind their way through the court system, there are a number of implications for institutional due diligence to be drawn from the rulings in this case at it stands at this point in time. Both rulings in this case emphasized the importance of GSU's good faith efforts to comply with copyright and fair use law. Consequently, it is prudent for institutions to demonstrate good faith by evaluating their policies, procedures and protocols in light of what is now known from this case by undertaking the following.

- Institutions should review and revise existing copyright policies and procedures to bring them into compliance with the rulings in this case.

- Institutions should remain alert for further developments in this case as well as other cases involving questions of copyright and fair use.

- Institutions should make sure relevant copyright and fair use compliance information is provided to faculty members, students, and other staff involved in the creation and delivery of electronic course materials and content.

- Institutions should make sure procedures and processes for obtaining required permissions are readily available to faculty members and relevant staff.

It bears noting that the rulings in the cases referred to herein involve the use of copyright protected materials that are owned and/or distributed via commercial enterprises. To the extent faculty members continue to choose to use such materials, adherence to applicable law is required. However, rulings such as those discussed herein also serve as a reminder that faculty members may choose to use other types of materials that avoid some or all of the complexity involved in undertaking the adoption of materials in reliance on fair use such as the adoption of resources published and distributed under an Open Access model. 


\section{REFERENCES}

1. Cambridge University Press, Oxford University Press, Inc., and Sage Publications, Inc. v. Carl V. Patton, in his official capacity as Georgia State University President, et al. United States District Court for the Northern District of Georgia, Atlanta Division. Civil Action No. 1-08-CV-1425, 2008.

2. Cambridge University Press, Oxford University Press, Inc., and Sage Publications, Inc. v. Carl V. Patton, in his official capacity as Georgia State University President, et al. Complaint. United States District Court for the Northern District of Georgia, Atlanta Division. Civil Action No. 1-08CV-1425, 2008.

3. Basic Books, Inc. v. Kinko’s Graphics Corp. 758 F. Supp. 1522 (S.D. New York, 1991).

4. Princeton University Press v. Michigan Documents Services 99 F. $3 d 1381$ (6 ${ }^{\text {th }}$ Cir., 1996).

5. Blackwell Publishing, Inc., Elsevier, Inc., Oxford University Press, Inc., Sage Publications, Inc., and John Wily \& Sons, Inc. v. Excel Research Group, LLC d/b/a Excel Test Preparation, Coursepacks \& Copies, and Norman Miller, Memorandum and Order Granting Plaintiff's Motion for Partial Summary Judgment, United States District Court for the Eastern Division of Michigan, Southern Division. Case No. 07-12731, 2009.

6. United States Constitution. $11^{\text {th }}$ Amendment. February 7, 1795.

7. Cambridge University Press, Oxford University Press, Inc., and Sage Publications, Inc. v. Carl V. Patton, in his official capacity as Georgia State University President, et al. Order. United States District Court for the Northern District of Georgia, Atlanta Division. Civil Action No. 1-08-CV1425, September 30, 2010.

8. Marketing Information Masters, Inc. v. The Board of Trustees of the California State University System and Robert A. Rauch. United States District Court for the Southern District of California. Order Granting in Part and Denying in Part Defendant's Motion to Dismiss. Civil No. o6cv1682 JAH (JMA). February 5, 2008.

9. Schrotenboer, B. "CSU Settles SDSU Copyright Law Suit." The San Diego Union Tribune. $\begin{array}{lllll}\text { Retrieved on } & \text { March } & 19, & \text { from: }\end{array}$ http://www.utsandiego.com/news/2009/feb/27/1s27sdsusuit223234-csu-settles-sdsu-copyrightlaws/. February 27, 2009.

10. Cambridge University Press, Oxford University Press, Inc., and Sage Publications, Inc. v. Carl V. Patton, in his official capacity as Georgia State University President, et al. Plaintiffs' Corrected Certificate of Interested Persons. United States District Court for the Northern District of Georgia, Atlanta Division. Civil Action No. 1-08-CV-1425, 2008.

11. Lowry, C.B. Letter to Tracey L. Armstrong. Dated November 11, 2010. Retrieved on March 28, 2012 from: http://www.arl.org/bm doc/ltccc-final.pdf.

12. Albanese, A. "Libraries Urge CCC to Reconsider its Funding of E-Reserve Copyright Case." Publishers Weekly. Retrieved on February 28, 2012 from: http://www.publishersweekly.com/pw/by-topic/digital/copyright/article/45257-libraries-urge-ccc-toreconsider-its-funding-of-e-reserve-copyright-case.html. November 19, 2010.

13. Allen, T. "Common Goals-AAP on the GSU E-reserve Lawsuit." Publishers Weekly. Retrieved on March 9, 2012 from: http://www.publishersweekly.com/pw/print/20110711/47931-commongoals-aap-on-the-gsu-e-reserve-lawsuit.html. July 11, 2011.

14. Cambridge University Press, Oxford University Press, Inc., and Sage Publications, Inc. v. Carl V. Patton, in his official capacity as Georgia State University President, et al. Order. United States District Court for the Northern District of Georgia, Atlanta Division. Civil Action No. 1-08-CV1425, August 11, 2010.

15. Cambridge University Press, Oxford University Press, Inc., and Sage Publications, Inc. v. Carl V. Patton, in his official capacity as Georgia State University President, et al. Order. United States 
District Court for the Northern District of Georgia, Atlanta Division. Civil Action No. 1-08-CV1425, August 12, 2010.

16. Cambridge University Press, Oxford University Press, Inc., and Sage Publications, Inc. v. Carl V. Patton, in his official capacity as Georgia State University President, et al. Plaintiff's Supplemental Filing in Response to the Court's August 11, 2010 and August 12, 2010 Orders. United States District Court for the Northern District of Georgia, Atlanta Division. Civil Action No. 1-08-CV-1425, August 20, 2010.

17. Cambridge University Press, Oxford University Press, Inc., and Sage Publications, Inc. v. Carl V. Patton, in his official capacity as Georgia State University President, et al. Defendant's Response to Plaintiff's Supplemental Filing. United States District Court for the Northern District of Georgia, Atlanta Division. Civil Action No. 1-08-CV-1425, August 30, 2010.

18. Digest of Education Statistics: 2010-Table 276. National Center for Education Statistics. U.S. Department of Education. Retrieved on April 3, 2012 from: http://nces.ed.gov/programs/digest/d10/tables/dt10_276.asp?referrer=list.

19. Cambridge University Press, Oxford University Press, Inc., and Sage Publications, Inc. v. Carl V. Patton, in his official capacity as Georgia State University President, et al. Order. United States District Court for the Northern District of Georgia, Atlanta Division. Civil Action No. 1-08-CV1425, May 11, 2012.

20. Cambridge University Press, Oxford University Press, Inc., and Sage Publications, Inc. v. Carl V. Patton, in his official capacity as Georgia State University President, et al. Proposed Injunctive Relief. United States District Court for the Northern District of Georgia, Atlanta Division. Civil Action No. 1-08-CV-1425, May 11, 2012.

21. Cambridge University Press, Oxford University Press, Inc., and Sage Publications, Inc. v. Carl V. Patton, in his official capacity as Georgia State University President, et al. Order. United States District Court for the Northern District of Georgia, Atlanta Division. Civil Action No. 1-08-CV1425, August 10, 2012.

22. Cambridge University Press, Oxford University Press, Inc., and Sage Publications, Inc. v. Carl V. Patton, in his official capacity as Georgia State University President, et al. Judgment. United States District Court for the Northern District of Georgia, Atlanta Division. Civil Action No. 1-08CV-1425, September 30, 2012.

23. Cambridge University Press, Oxford University Press, Inc., and Sage Publications, Inc. v. Carl V. Patton, in his official capacity as Georgia State University President, et al. Notice of Appeal. United States District Court for the Northern District of Georgia, Atlanta Division. Civil Action No. 1-08-CV-1425, September 10, 2012.

24. Cambridge University Press, Oxford University Press, Inc., and Sage Publications, Inc. v. Carl V. Patton, in his official capacity as Georgia State University President, et al. Order. United States District Court for the Northern District of Georgia, Atlanta Division. Civil Action No. 1-08-CV1425, October 2, 2012.

*Portions of this article are based on or appeared as blog entries at Sloan-C.org. 